\title{
ARMED FORCES AND POLITICS \\ IN THE BOLIVARIAN REVOLUTION ${ }^{1}$
}

ABSTRACT The set of changes which were introduced in Venezuelan society in February 1999 with the establishment of the Bolivarian Revolution found a privileged expression in the National Armed Forces members' way of thinking, organization and action, to the point that it significantly impacted the civil-military relations model Venezuela implemented during the liberal representative democratic system (1958-1998). Currently, an emerging type of civil-military relations has been established which is mainly marked, by military politicization and the military colonization of Venezuelan civil services. A critical interpretation of this process is the focus of this paper.

KEY WORDS Venezuela, Bolivarian Revolution, Hugo Chávez, Venezuelan National Armed Forces, Politicization of Venezuelan National Armed Forces, military colonization of Venezuelan civil service.

\section{INTRODUCTION}

On February 4th, and November 27th 1992, a populist and radical faction of Venezuelan Armed Forces tried, without success, to overthrow the social democratic Venezuelan government constitutionally formed and headed at that time by President Carlos Andrés Pérez. However, the insurgents' military defeat did not mean their political defeat. From that moment on, it began to shine for them, in public opinion, a star

This article was submitted for publication before the death of Hugo Chávez. 
which was largely built by the combined actions of two factors of singular projection in the minds of the people. ${ }^{2}$ First: the promotion of these military uprisings and the ideology and biography of their main actors through mass media. From the eighth decade of last century, most of the mass media was dedicated to criticizing liberal democracy representatives established in the country since 1958, because they acted as representatives of the triumphant antipolitics in Latin America in those years. ${ }^{3}$ Secondly: the profusion of popular works supporting insurgents' armed actions, most of them written by important national and foreign authors, eager as they were, given their ideological sympathies with these coups, to stoke the flame of political instability that engulfed Venezuelan society since.

For six years, some of the military rebels construed a strategy to get political offices established in the Constitution; for example, Lieutenant Colonel (Army) Francisco Arias Cárdenas, who won Zulia state governorship. Others, for example, Lieutenant Colonel (Army) Hugo Chávez, toured the country calling for abstention for the 1993 presidential elections and 1995 municipal elections. Then, the 1992 military rebels were grouped in a political organization called Movimiento Quinta República (MVR), officially established in October 1997 and now transformed into Partido Socialista Unido de Venezuela (PSUV), with the purpose of entering the race to achieve State and government control by their through participation in the scheduled 1998 elections.

In November 1998 elections run to vote for National Congress representatives and senators, the MVR became the second political force achieving a total of 45 representatives and 13 senators. On that same election, the MVR won $30 \%$ of governorships, that is, 7 over 23, alone or in electoral agreements signed with other allied political parties. Those were Anzoátegui state, Aragua state, Barinas state, Guárico state, Lara state, Vargas state and Zulia state. It also held the second position with respect to states legislature's members. There, 75 of its members and/or supporters won seats.

A month later, Hugo Chávez was elected president with 3,673,685 votes $(56.20 \%$ of votes counted all over the country). The MVR obtained 2,625,839 ( $40.17 \%$ at national scale). The remaining 1,047,846 (16.03\%) were won by political parties and groups al-

2 More on the populist nature and radical character of military political insurrections occurred in Venezuela in 1992, see: L.A. Buttó, 'El Nuevo Profesionalismo Militar de Seguridad Interna y Desarrollo Nacional. Un ejercicio de reflexión académica como hipótesis para entender las relaciones civiles y militares en Venezuela contemporánea' in D. Irwin, F. Langue (coord.), Militares y Sociedad en Venezuela. Un manual sobre las relaciones civiles y militares, el control civil y referencias metodológicas sobre la historia inmediata. Cuando la calle arde y el aula reflexiona, Caracas 2003, pp. 129-146. Also: L.A. Buttó, 'Nuevo profesionalismo militar de seguridad interna y desarrollo nacional e intervención política de militares populistas y radicales en Venezuela' in D. Irwin, F. Langue (coord.), Militares y Poder en Venezuela. Ensayos históricos vinculados con las relaciones civiles y militares venezolanas, Caracas 2005, pp. 139-177. Further: L.A. Buttó, 'Venezuela 1992: bases ideológicas de las insurrecciones militares', Asian Journal of Latin American Studies, Vol. 21, № 2 (2008), pp. 35-67. Equally: L.A. Buttó, 'Exégesis ideológica de las insurrecciones militares venezolanas de 1992', Europa \& América Latina, revue $\mathrm{N}^{\circ} 5$ (2010), pp. 149-161.

3 For a detailed explanation of the antipolitics in Latin America; see: B. Loveman, T.M. Davies Jr. (eds.), The politics of antipolitics. The military in Latin America, Lincoln 1989. 
lied to MVR. This alliance of parties was called Polo Patriótico. Among the political parties grouped in Polo Patriótico were the main Venezuelan leftist parties: Movimiento al Socialismo, Patria para Todos, Partido Comunista de Venezuela and Movimiento Electoral del Pueblo.

In the successive elections held in Venezuela from 1999 until 2012, the electoral proposals submitted by the PSUV have been accepted by the majority of the electors. These elections were a referendum to elect the Constituent Assembly in 1999, the election of Constituent Assembly representatives in 1999, the new Constitution approval in 1999, the re-legitimization of government in 2000, the recall referendum in 2004, governors and mayors election in 2004, the election of National Assembly representatives in 2005 (opposition abstained from participating in this election) and presidential re-election in 2006.

Meanwhile, the opposition defeated the government twice. In December 2007, Venezuelan voters rejected the constitutional reform aimed to install a socialist economy and the indefinite presidential re-election. However, the indefinite presidential re-election was approved in a referendum the following year. In the National Assembly elections held in September 2010, the opposition won 50.36\% of votes and the government got $48.13 \%$. Furthermore, in elections for governorships held in 2008, the opposition won five governorships in the most populous states, including Caracas Mayor City Hall (in Spanish: Alcaldia Mayor de Caracas).

The rise to power of the movement led by President Chávez marked the beginning of a process of deep changes in Venezuelan politics, including civil-military relations. From that moment, Armed Forces were politicized and the military have colonized the civil service in Venezuela. The main objective of this paper is to explain both processes.

\section{THE POLITICIZATION OF VENEZUELAN ARMED FORCES}

The legal process of Venezuelan Armed Forces politicization began in 1999. In this regard, the initial step was taken in the Constitution drafted that year by the National Constituent Assembly. The 1961 Constitution established that Venezuelan National Armed Forces were an apolitical, obedient and non-deliberative institution. ${ }^{4}$ That is to say, in accordance to the 1961 Constitution, Venezuelan military could not perform any kind of political action. Article 328 of the 1999 Constitution eliminated the ban on the military to deliberate on politics, as well as the adjective apolitical. In fact, the

\footnotetext{
Constitución de la República de Venezuela, Gaceta Oficial de la República de Venezuela, 662 (Extraordinario), 23 January 1961. Original article in Spanish: "Las Fuerzas Armadas Nacionales forman una institución apolítica obediente y no deliberante, organizada por el Estado para asegurar la defensa nacional, la estabilidad de las instituciones democráticas y el respeto a la Constitución y a las leyes, cuyo acatamiento estará siempre por encima de cualquier otra obligación. Las Fuerzas Armadas Nacionales estarán al servicio de la República, y en ningún caso al de una persona o parcialidad política”.
} 
1999 Constitution only states that Venezuelan Armed Forces are a professional institution and their members do not have political militancy. ${ }^{5}$

From 1999, Venezuelan military began to be active in politics. In this respect, the only restriction for Venezuelan military is that they cannot be members of a political party. So, from that moment, Venezuelan military can support and defend the political party and the economic model they want as well as opposing and attacking the political party and the economic model they want. However, the legalization of military intervention in politics introduced into the 1999 Constitution was not limited to the abovementioned.

In article 328 of the 1999 Constitution, Venezuelan Armed Forces were defined as an institution, among other functions and objectives, organized by the Venezuelan State for active participation in national development. That is to say, a state institution that can legally participate in efforts that lead to establish in Venezuelan society, the economic model outlined in the constitution and in the development plans designed and implemented by the Venezuelan government. That is to say, an agency with authority and capacity that can develop and/or to implement public policies. These public policies can be economic, social, cultural, scientific and technological. Therefore, with the entry into force of constitutional article 328, Venezuelan Armed Forces were erected legally as political actors with direct involvement in the Venezuelan State and government control.

For the reasons stated above, President Chávez always says that Venezuelan military must be political actors. For example, in mid 2005, he said that the Armed Forces are the Venezuelan State political resource and he said that Venezuelan military should not be apolitical because they must not confuse politics with politicking. That is to say, Venezuelan military can be politicians but they cannot be members of a political party ${ }^{6}$. On December 28th, 2006, President Chávez said that all Venezuelan military must feel as political actors and they should act as politicians. Furthermore, at that time, President Chávez said that Venezuelan military "cannot be" politicians but they "should be" politicians.?

On April 2nd, 2007, President Chávez expressed that it was absolutely false that Venezuelan military must be apolitical and that they must repeat the slogan "Fatherland, Socialism or Death" (In Spanish: Patria, Socialismo o Muerte) because they make it clear what is their political ideology. At that time, President Chávez warned that

Constitución de la República Bolivariana de Venezuela, Gaceta Oficial de la República Bolivariana de Venezuela, 5.453 (Extraordinario), 24 March 2000. Original article in Spanish: "La Fuerza Armada Nacional constituye una institución esencialmente profesional, sin militancia política, organizada por el Estado para garantizar la independencia y soberanía de la Nación, y asegurar la integridad del espacio geográfico mediante la defensa militar, la cooperación en el mantenimiento del orden interno y la participación activa en el desarrollo nacional, de acuerdo con esta Constitución y con la ley”.

6 M.D. Espinoza, 'Bajo el signo del militar-político y el ciudadano-soldado', El Universal (Caracas), 24 February 2008, p. 1-4.

$7 \quad$ H.R. Chávez (speaker), Salutación de Fin de Año del presidente de la República Bolivariana de Venezuela a la Fuerza Armada Nacional (On TV), Caracas, Venezolana de Televisión, 28 December 2006. 
Venezuelan military who do not believe in socialist ideology should be removed from the active service. ${ }^{8}$ By the way, after President Chávez was diagnosed with cancer, the slogan "Fatherland, Socialism or Death" was changed by Independence and Socialist Motherland. We will live and win (In Spanish: Independencia y Patria Socialista. Viviremos y Venceremos). Is it a simple superstition? I do not know. It could be.

But the issue did not stop there. Today, President Chávez defines Venezuelan Armed Forces as Bolivarian, Revolutionary, Anti-Imperialist, Socialist and Chavistas. The latter means that Venezuelan Armed Forces are President Chávez unconditional followers. Venezuelan military officers also define Venezuelan Armed Forces in the same way. In fact, official documents signed by members of Venezuelan Military High Command point out that Venezuelan Armed Forces have to be Bolivarian, Revolutionary, Anti-Imperialist, Socialist and Chavistas and the same Venezuelan Military High Command ordered the inclusion of these five words as part of the daily military salute from April 2012. ' That is to say, with no doubt, Venezuelan Military High Command is fully identified with President Chávez political ideology.

In other context, in the Bolivarian National Armed Forces Organic Law (in Spanish: Ley Orgánica de la Fuerza Armada Nacional Bolivariana; LOFANB; March 2011), the political figure of Venezuelan Armed Forces commander-in-chief became the highest operational level of these Armed Forces. In article 6 of the LOFANB, it can be read that the President of the Bolivarian Republic of Venezuela has the military rank of commander-in-chief, he is the highest authority of the Bolivarian National Armed Forces, he plays the supreme command of the Bolivarian National Armed Forces, he directs the overall development of military operations, he sets and activates Operation Theatres in the strategic regions for territorial defense. ${ }^{10}$

In other words, from that moment, the commander-in-chief is not a symbolic position. That is to say, the commander-in-chief is now a real military hierarchy. Then, as the President is the commander-in-chief of Venezuelan Armed Forces, so he became a political actor. This means that with the LOFANB enforcement, the head of Venezuelan Armed Forces has been politicized and the presidency of the Bolivarian Republic of Venezuela has been militarized.

This very important change was a praetorian inspiration action. Its main objective was to provide Venezuelan Armed Forces a leading role in the management of the

$8 \quad$ H.R. Chávez (speaker), Discurso pronunciado en el acto de entrega de préstamos hipotecarios a personal de la Fuerza Armada Nacional (On TV), Caracas, Venezolana de Televisión, 2 April 2007.

9 'Nuevo saludo militar: Bolivariano, Revolucionario, Antiimperialista, Socialista y Chavista', PRIMICIA.COM, Puerto Ordaz (Venezuela), 1 April 2011, at <http://www.primicia.com.ve/index.php/nacion/item/13150-nuevo-saludo-militar-bolivariano-revolucionario-antiimperialista-socialista-y-chavista.html>, 2 June 2012.

10 Decreto con Rango, Valor y Fuerza de Ley Orgánica de Reforma de la Ley Orgánica de la Fuerza Armada Nacional Bolivariana, Gaceta Oficial de la República Bolivariana de Venezuela, número 8.096, 9 March 2011. Original article in Spanish: (...) El Presidente o Presidenta de la República tiene el grado militar de Comandante en Jefe y es la máxima autoridad jerárquica de la Fuerza Armada Nacional Bolivariana (...) Ejerce el mando supremo de ésta (...) Dirige el desarrollo general de las operaciones, define y activa el área de conflicto, los teatros de operaciones y regiones estratégicas de defensa integral. 
Venezuelan State and government. In this regard, Herrera Jiménez said (...) The point of convergence is the President of the Republic. In the first case, as head of State, advised by the Nation Defense Council. In the second: in his capacity as head of Government, within the framework of the Council of Ministers. ${ }^{11}$

Article 4 of the LOFANB establishes that one of the functions of Venezuelan Armed Forces is to support other Venezuelan state agencies in the implementation of social, political, cultural, geographical, environmental and economic programs. ${ }^{12}$ That is to say, Venezuelan Armed Forces are directly involved in building of the economic model and political project designed by President Chávez government. In other words, Venezuelan military are now makers of public policies and currently political actors.

President Chávez always says that the Bolivarian Revolution is peaceful but it has weapons. As well as, with the LOFANB implementation, Venezuelan Armed Forces became the military wing of Bolivarian Revolution. This was done by creating the Bolivarian Militia because this is an armed agency other than the Army, the Navy, the Aviation and the National Guard whose commander-in-chief is President Chávez. Almost verbatim, article 43 of the LOFANB states that the Bolivarian Militia is a special agency organized by the Venezuelan State, designed to complement to Bolivarian National Armed Forces in the Nation defense and it depends directly on the President of the Republic and commander-in-chief of Bolivarian National Armed Forces. ${ }^{13}$

In fact, Bolivarian Militia has the same structure as Venezuelan Armed Forces. In article 5 of the LOFANB, it can be read that Bolivarian Militia has a General Commander and it has a Second Commander. It also has a Chief of Staff and its own operating units. ${ }^{14}$ As stated in articles 50 and 51 of the LOFANB, all Bolivarian Militia members are volunteers; registration and training are made by the Bolivarian Militia General Command. That means registration and training of Bolivarian Militia mem-

11 H. Herrera Jiménez, La Doctrina Militar Bolivariana. El Nuevo Sistema de Seguridad y Defensa Venezolano, Caracas 2006, p. 243. Free translation made by Luis Alberto Buttó. Original version in Spanish: (...) El punto de convergencia es el Presidente de la República. En el primer caso, como Jefe de Estado, asesorado por el Consejo de Defensa de la Nación. En el segundo, en su condición de Jefe de Gobierno, en el marco del Consejo de Ministros.

12 Decreto con Rango, Valor y Fuerza de Ley Orgánica de Reforma de la Ley Orgánica de la Fuerza Armada Nacional Bolivariana. Original article in Spanish: Apoyar a los distintos niveles y ramas del Poder Público en la ejecución de tareas vinculadas a los ámbitos social, politico, cultural, geográfico, ambiental, económico y en operaciones de protección civil en situaciones de desastres en el marco de los planes correspondientes.

13 Ibid. Original article in Spanish: La Milicia Bolivariana es un cuerpo especial organizado por el Estado Venezolano (...) destinada a complementar a la Fuerza Armada Nacional Bolivariana en la Defensa Integral de la Nación (...) La Milicia Bolivariana depende directamente del Presidente o Presidenta de la República y Comandante en Jefe de la Fuerza Armada Nacional Bolivariana.

14 Ibid. Original article in Spanish: La Milicia Bolivariana está organizada por un Comando General, Segundo Comando y Jefatura de Estado Mayor, Agrupamientos, Unidades de Milicia Territorial, Cuerpos Combatientes y los órganos operativos y administrativos funcionales necesarios para coadyuvar en la ejecución de acciones de seguridad, defensa y desarrollo integral de la Nación. 
bers are carried out by the presidency of the Republic. In addition, many workers of the Venezuelan State must be members of the Bolivarian Militia. ${ }^{15}$ For this reason, it is said that the fundamental requirement to enlist into the Bolivarian Militia is to believe in President Chávez's political project ideology.

Last but not least, it should be taken into account an important fact related to Bolivarian Militia. The Bolivarian Militia has more members than the Bolivarian National Armed Forces. In 2009, the Bolivarian National Armed Forces had 90,000 members. ${ }^{16}$ In December 2008, general (Army) Carlos Freites Reyes (he was Bolivarian Militia General Commander, at that time) said that the Bolivarian Militia had 850,000 members. ${ }^{17}$ According to this General, the Bolivarian Militia would have 1,500,000 at the end of 2009. ${ }^{18}$ That is to say, the Bolivarian Militia is the genuine Praetorian Guard of President Chávez.

\section{THE MILITARY COLONIZATION OF VENEZUELAN CIVIL SERVICE}

Article 131 of 1961 Constitution prohibited being civil and military authority at the same time. ${ }^{19}$ This prohibition was removed in the 1999 Constitution. Thus, from that moment, Venezuelan military may hold posts in the civil service without any restrictions. Thus, there began the military colonization of Venezuelan civil service. According to Finer, military colonization is conceptualized as follows: “(...) 'Colonization' means that military have spilled over from the strict armed-service hierarchy into political parties or trade unions, government corporations, or civil bureaucracy (...)"20 In other words, a procedure through which military ends up being a very important source of staff for civil service.

15 Ibid. Original articles in Spanish: Los Cuerpos Combatientes son unidades conformadas por ciudadanos y ciudadanas que laboran en instituciones públicas o privadas, que de manera voluntaria son registrados o registradas, organizados u organizadas y adiestrados y adiestradas por el Comando General de la Milicia Bolivariana (...) La Milicia Territorial está constituida por los ciudadanos y ciudadanas que voluntariamente se organicen para cumplir funciones de Defensa Integral de la Nación (...) y deberán estar registrados por la Comandancia General de la Milicia Bolivariana, quedando bajo su mando y conducción.

16 Red de Seguridad y Defensa de América Latina, 'Atlas Comparativo de la Defensa en América Latina, at <http://atlas.resdal.org.ar>, 5 May 2009.

17 Sala de Prensa de Minuto 59, 'Milicia Nacional Bolivariana necesita un millón y medio de voluntarios', at <http://www.minuto59.com/primera-pagina/milicia-nacional-bolivariana-necesita-un-millon-y-medio-de-voluntarios>, 2 May 2009.

18 Ibid.

19 Constitución de la República de Venezuela, Gaceta Oficial de la República de Venezuela, 662 (Extraordinario), 23 January January1961. Original article in Spanish: La autoridad militar y la civil no podrán ejercerse simultáneamente por un mismo funcionario, excepto por el Presidente de la República, quien será, por razón de su cargo, Comandante en Jefe de las Fuerzas Armadas Nacionales.

20 S.E. Finer, 'The morphology of military regimes' in R. Kolkowicz, A. Korbonski (eds.), Soldiers, Peasants and Bureaucrats. Civil-Military Relations in Communist and Modernizing Societies, London 1982, p. 297. 
In my doctoral dissertation, a list of government posts occupied by Venezuelan military officers during the 1999-2010 period was drawn. Obviously, the complete listing cannot be shown in this paper but some comments can be made about this list. In this relationship, 720 important government jobs occupied by military officers were identified, with military ranks and full names, with the caveat that they correspond to what can be conceptualized as civil service higher levels. ${ }^{21}$ In other words, the sum included in the list presented did not reflect the complex during the 11 years considered. That is, in statistical terms, the quantification shown was only a representative sample of the phenomenon. Given the case that, when a military officer is appointed to a government office, generally, this person chooses other military personnel to become part of his/her team, these 720 positions must be multiplied by at least four. ${ }^{22}$

However, the most important thing is not just the amount. It is also necessary to know the importance of the posts occupied by military officers and if they allow control of very important aspects of Venezuelan society, such as health, police or social programs. That is, if these agencies led by military officers carry out government's main programs, it does not matter that the environment minister be a civil bureaucrat. It is relevant if the vice president is a military officer. It is important if the head of the national intelligence service is a military officer. Such things have occurred in Venezuela during this period.

It is also significant if the main social programs are carried out by the Armed Forces. Today, Venezuelan Armed Forces participate in housing building, food distribution, health programs, and so on. The best example of this was the so-called Plan Bolivar 2000. The Plan Bolivar 2000 was the first great social program carried out by President Chávez government. For example, the Plan Bolivar 2000 was commissioned to build hundreds of schools, roads and houses. It was also commissioned to distribute tons of food and provide medical assistance to thousands of people, since it was designed and implemented by Venezuelan Armed Forces.

The military colonization of Venezuelan civil service could evolve into a military government. This military government could be a direct military government or an indirect military government. According to Finer,

It is possible to distinguish three main kinds of military regime. The first - the stereotype - is the direct military government. By this I mean that military leaders have the Government direct responsibility although they may appoint a civilian cabinet to which they give orders. This kind is divided in two: the direct way and the almost direct civil way.

21 L.A. Buttó, Venezuela 1992. Aproximación Histórica a las Bases Ideológicas de las Insurrecciones Militares, unpublished manuscript, Caracas 2010, pp. 186-259.

22 About military colonization of the Venezuelan civil service; see also: L.A. Buttó, 'Gobiernos Militares y Democracia: el maridaje imposible’ in D. Irwin, H. Castillo, F. Langue (coords.), Pretorianismo venezolano del siglo XXI. Ensayos sobre las relaciones civiles y militares venezolanas, Caracas 2007, pp. 173-257. Moreover: L.A. Buttó, 'Venezuela 1999-2008: Relaciones Civiles y Militares en la V República' in C. Fermín, L.A. Buttó, H. Hurtado Grooscors, Una lectura sociológica de la Venezuela actual V, Caracas 2009, pp. 55-104. Likewise: L.A. Buttó, 'Marcos Pérez Jiménez-Hugo Chávez: la élite militar al asalto del poder' in A. Cardozo Uzcátegui (ed.), Chavismo. Entre la utopia y la pesadilla, Vitoria-Gasteiz (España) 2012, pp. 224-263. 
In this latter, military leaders are seeking some false way, or forced, of legitimacy through popular plebiscite or through the recognition by a dominated parliament, and so on. At the other extreme is the indirect military government. Nominally, a civilian government exercises the authority but it is really a facade because military leaders give instructions to civilians. This kind also splits in two. In the first, the military influence covers the entire field of political activity. In the second, however, it is an intermittent activity often limited to simple veto more than a positive program. ${ }^{23}$

Today, all the situations stated above are a reality in Venezuela. There are civilians exercising governmental functions but the president is a military officer, many ministers and officials are military officers and many heads and officials of State-owned enterprises are military officers, too. In addition, many PSUV leaders are military officers as Lieutenant (Army) Diosdado Cabello who is its first vice-president. He is also the National Assembly president. That is to say, military officers have taken the most important political and economic decisions in the country. For these reasons, I think that it is not an exaggeration to say that Venezuelan government is now a military government.

On December 13th, 1999, President Chávez himself acknowledged that his government was a military government. Verbatim, at that time, President Chávez said that his government was a government of the Armed Forces but he also said that he never would reveal it to the public. President Chávez said this in a meeting with the heads of regional military units. This meeting was carried out in the country's main Military Fort, the so-called Fuerte Tiuna. The goal of this meeting was to coordinate logistical and operational aspects of the so-called Plan República which is the military deployment that is performed in Venezuela when elections are going to take place. Let us remember that in December of that year there was a referendum to approve a new Constitution.

President Chávez's confession about his military government (a government of the Armed Forces) made clear the goal of military colonization of Venezuelan civil service and the politicization of Venezuelan Armed Forces. These praetorian actions are tools to build a military regime which perhaps does not look very much alike the military ones in the Latin-American of seventies and eighties. It is worth pointing out that this is a new kind of military government that is not the product of a coup d'état but the prod-

23 S.E. Finer, Governo Comparado, Brasilia 1981, pp. 481-482. Free translation made by Luis Alberto Buttó. Original version in Portuguese: é possivel distinguir três tipos principais de regime militar. O primeiro - o estereótipo - é o governo militar "directo". Com isso quero dizer que os líderes militares assumen eles própios a responsabilidade pelo governo, embora possam nomear um gabinete civil para executar suas ordens. Esse tipo se divide em dois: a forma "direta" e a forma "direta, quase civil". Nesta última, os lideres militares procuram alguma forma falsa, ou forçada, de legitimação, mediante o plebiscito popular, mediante o reconhecimento por uma assabléia dominada, e assim por diante. No outro extremo, está o "governo militar indireto". Nominalmente, um governo civil exerce a autoridade, mas isso na prática é uma fachada para os líderes militares, que dão suas instruções. Esse tipo também se divide em dois. No primeiro, a influência de bastidores dos militares abarca todo o campo da atividade política. No segundo, no entanto, é uma atividade intermitente, freqüentemente limitada ao simples veto, mais do que a um programa positivo. 
uct of democratic elections. Evidently, the leaders of these new military governments do not govern democratically although they have been elected democratically as said by former US Secretary of State Condoleezza Rice. ${ }^{24}$ In fact, no military government will ever be a democratic government. It is impossible. ${ }^{25}$ In this regard, it is necessary to remember what Escovar Salom said,

In Latin America, it is necessary to maintain a clear demarcation line against the many endeavors to militarize the policy of past or present, by becoming society and the Republic in barracks. The Republic is a system of civilian life, there is no scenario for armored divisions which move by orders brought from a centre. The republic is dialog, persuasion, vital dialectic. The republic is plural. The barracks are unique, because they belong to an institution at the service of the State, of vertical nature, exercise that is part of the State but that is not the whole State. ${ }^{26}$

President Chávez's revelation about what he said on that moment was done by General (Army) Gonzalo García Ordóñez on March 25 ${ }^{\text {th }}$, 2004, in a TV show. ${ }^{27}$ Until April 2004, General García Ordóñez held important posts in President Chávez government. First, General García Ordóñez was the head of the Joint Command of Venezuelan National Armed Forces (in Spanish: Comando Unificado de la Fuerza Armada Nacional). Later, he was Venezuela's Ambassador in Bolivia. General García Ordóñez left President Chávez government during April 2002 coup d'état. Obviously, General García Ordóñez was at the meeting mentioned in the previous paragraphs.

However, it is a striking fact that General García Ordóñez never mentioned anything about this meeting until 2004. He did so after leaving President Chávez government, when he expressed what President Chávez had said at that meeting while the other military officers never spoke a word about it. That is to say, until now, other military officers have chosen to remain silent about this meeting. Why? Ii is unknown but it is perhaps these military officers did not find any problem regarding the fact that Venezuelan government was a military one as President Chávez stated at that moment. As usual, history teaches: some military officers never criticized President Chávez government while they were partners in this military government. They only saw the shortcomings of President Chávez government of once that they were no longer his favorites.

24 AFP-AP-ANSA, 'Chávez es una fuerza negativa en la región', El Nacional (Caracas), 19 January 2005, p. A-11.

25 About the reasons for which a military government is never democratic; see: L.A. Buttó, 'Gobiernos Militares....

26 R. Escobar Salom, 'El desafío autoritario', El Nacional (Caracas), 10 June 2006, p. A-7. Free translation made by Luis Alberto Buttó. Original version in Spanish: En Iberoamérica hay que mantener un claro deslinde frente a los numerosos empeños del pasado o del presente por militarizar la politica, por convertir la sociedad y la república en un cuartel. La república es un sistema de vida civil, no es escenario de divisiones blindadas o de infanterías que se desplazan por órdenes que emanan de un centro. La república es diálogo, persuasión, dialéctica vital. La república es plural. El cuartel es singular, porque pertenece a una institución al servicio del Estado de naturaleza vertical, ejercicio que es parte del Estado pero que no es todo el Estado.

27 C. Fernández (presenter), Triángulo (TV Show), Caracas, TELEVEN, 25 March 2004. 


\section{CONCLUSIONS}

Military participate in politics to achieve three goals. The first of these goals is to gain political power in a country. When military achieve political power of a country, they can exercise this political power directly or in combination with civilians who believe that military must be political actors. In this way, military can impose on a country, the political project and the economic model they prefer. The military who rebelled in 1992 achieved this goal when they won the 1998 elections in December. Thereafter, this military group has won all the presidential elections in Venezuela.

On the other hand, since 1999, Venezuelan Armed Forces have successfully colonized Venezuelan civil service. It is not a secret that today military officers control ministers, governorships, mayoralties, public corporations and so on. Military officers are even representatives in the National Assembly and some have been judges in the Supreme Court of Justice (in Spanish: Tribunal Supremo de Justicia) as Colonel (Army) Eladio Aponte who was dismissed by the National Assembly because he had ties with drug dealers. Colonel Aponte was also president of the Martial Court. In other words, since Lieutenant Colonel (Army) Hugo Chávez was sworn as president, military officers started to control without any problem Venezuelan State and government.

The second of these goals is that the Armed Forces will become the utmost arbiter of political conflicts that occur in the country. General (Army) Henry Rangel Silva was the head of the Joint Command of the Venezuelan National Armed Forces (in Spanish: Comando Estratégico Operacional) in June 2011. At that moment, General Rangel Silva said that Venezuelan Armed Forces were completely loyal to President Chávez. He also said that Venezuelan Armed Forces would not accept the triumph of political parties opposed to President Chávez in the event that these political parties will win the presidential elections of $2012 .^{28}$

In other words, General Rangel Silva said that Venezuelan Armed Forces decide who governs in Venezuela. Obviously, according to him only President Chávez should govern Venezuela. With this statement, General Rangel Silva made clear that Venezuelan Armed Forces are today the utmost arbiter of Venezuelan political conflicts. At this same moment that this paragraph is being written, General Rangel Silva is Venezuela's Minister of Defense.

The third of these objectives is that Armed Forces become the governmental armed wing. In this way, a serious political crisis could take place in the country but the government would never run the risk of being deposed. Today, the Bolivarian Revolution can face any kind of popular rebellion with the Bolivarian Militia. When I say popular rebellion I am referring to events such as those that occurred on April 11th, 2002, when a huge popular demonstration marked the beginning of the events that led to

28 J.L. Carrillo, 'En las FF.AA. nos casamos con el proyecto de país del Comandante Hugo Chávez' (Interview with General Henry Rangel Silva), at <http://www.noticias24.com/actualidad/noticia/179689/venezuela-adquirio-tanques-t72-btr-80-y-btp3-y-misiles-para-defender-las-costas $>, 30$ June 2011. 
the overthrow of President Chávez at that time. More than a million people marched in Caracas streets that day. Without any doubt, this was the biggest popular outdoor demonstration in the contemporary history of Venezuela.

When it is said popular rebellion, it also refers to events such as those that occurred in February 1989 when popular looting was repressed by Venezuelan Armed Forces. At that time, the repression carried out by Venezuelan Armed Forces caused thousands of deaths. President Chávez has always said that February 1989 events inspired him to perform the 1992 coup d'état because the repression suffered by people that day was unjust and wild. However, many of the military officers who carried out such repression are today part of President Chávez government. None of them has been judged in court for the excesses that they made on that day. It seems that the important thing is not what they did in the past; it is that they support President Chávez government in the present. It seems that the victims did not matter. It seems that politics does matter.

On the other hand, we must remember that the Bolivarian Militia is organized to deal with attacks by foreign Armed Forces and attacks carried out from inside the country. The question is: how do the leaders of the Bolivarian Revolution understand the attacks carried out from inside the country? I wonder if these attacks are understood as a military rebellion done by the rest of Venezuelan Armed Forces. I do not know. I only know that President Chávez has said many times that Venezuelan Armed Forces will never allow a coup d'état like the one on April 2002 and I only know that he has said this after the Bolivarian Militia was created. Is it a coincidence? I doubt it very much.

The combined action of Venezuelan Armed Forces politicization and the military colonization of Venezuelan civil service have caused a radical change in the country civil-military relations. In reality, these relationships are now military-civil relations more than civil-military relations because military are politically stronger than civilians. Today, military are not subordinate to civilians. On the contrary, they became political actors and acting as such they seek to say what should be the political destiny of Venezuelans. This situation is a very serious threat to Venezuelan democracy because political actors are no longer competing equally. Now, political parties opposing President Chávez government have to compete with a political actor that is armed and that warns that it does not recognize the fact that political parties opposed to Chávez may be the government in the future. That is to say, Venezuelan Armed Forces want to be (or they are) the outmost arbiter of Venezuelan politics.

The politicization of Venezuelan Armed Forces and the military colonization of Venezuelan civil service also show that Venezuelan military have full autonomy of action. The foregoing and the fact that Venezuelan military are not subordinate to civilians mean that today there is no civilian control in Venezuela. Precisely, the goal of civilian control is that military would not be autonomous, that military should be subordinated to civilians and cannot be political actors, due to the fact that without civilian control, there is no a real democracy because as Norden explained it can only be democratic (...) a system in which elected officials govern unchecked by armed 
forces (...). ${ }^{29}$ In any case, if civilian control does not return to be a reality in Venezuela any future government will not have enough governance, that is to say, there will be no true democracy in Venezuela.

To recover civilian control in Venezuela, it is necessary to carry out deep legal and institutional changes. In first place, it is necessary to change the 1999 Constitution in the chapter dealing with Armed Forces. These changes should clearly establish that military should never be political actors and they should be obedient and not deliberative.

The LOFANB must be also reformed in particular to dissolve the Bolivarian Militia, because it is not necessary for the Nation external defense if there are capable Armed Forces. In addition, it is inconvenient that this Militia exists because it is a heavily politicized armed agency that is identified with President Chávez government. Military cannot be identified with a political leader, since they must be identified with the country and be obedient to the government that people has chosen democratically.

On the other hand, it should be banned outright that military would occupy civilian posts in civil service while they are active. The military colonization of civil service should be avoided at all costs since it allows military to control the State and its government. Once these changes have been made if some military try to keep on behaving like political actors then the State must enforce the law and take them to court if it is necessary.

Once Irwin pointed out that in Venezuelan nineteenth century was the century of warlords and the twentieth was the one of military. ${ }^{30}$ Certainly, from 1830 until 1999 , civilians ruled Venezuela just for 46 years. 41 of those years passed between 1958 and 1999. I wonder if the twenty-first century will be civilians the century of. I do not know but I hope so. In the future, Venezuela must be a civilian republic as dreamed by their founding fathers.

\section{REFERENCES}

AFP-AP-ANSA, 'Chávez es una fuerza negativa en la región', El Nacional (Caracas), 19 January 2005, p. A-11.

Buttó L.A., 'El Nuevo Profesionalismo Militar de Seguridad Interna y Desarrollo Nacional. Un ejercicio de reflexión académica como hipótesis para entender las relaciones civiles y militares en Venezuela contemporánea' in D. Irwin, F. Langue (coords.), Militares y Sociedad en Venezuela. Un manual sobre las relaciones civiles y militares, el control civil y referencias metodológicas sobre la historia inmediata. Cuando la calle arde y el aula reflexiona, Caracas 2003, pp. 129-146.

Buttó, L.A., 'Exégesis ideológica de las insurrecciones militares venezolanas de 1992', Europa \& América Latina, revue No 5 (2010), pp. 149-161.

29 D. Norden, 'Crisis without coups in Latin America: the role of the international community in sustaining democracy', paper presented at XXV International Congress of the Latin American Studies Association, Las Vegas (USA), October 2004, p. 3. 
Buttó L.A., 'Gobiernos Militares y Democracia: el maridaje imposible' in D. Irwin, H. Castillo, F. Langue (coords.), Pretorianismo venezolano del siglo XXI. Ensayos sobre las relaciones civiles y militares venezolanas, Caracas 2007, pp. 173-257.

Buttó L.A., 'Marcos Pérez Jiménez-Hugo Chávez: la élite militar al asalto del poder' in A. Cardozo Uzcátegui (ed.), Chavismo. Entre la utopia y la pesadilla, Vitoria-Gasteiz (España) 2012, pp. 224-263.

Buttó L.A., 'Nuevo profesionalismo militar de seguridad interna y desarrollo nacional e intervención política de militares populistas y radicales en Venezuela' in D. Irwin, F. Langue (coords.), Militares y poder en Venezuela. Un manual sobre las relaciones civiles y militares, el control civil y referencias metodológicas sobre la historia inmediata. Cuando la calle arde y el aula reflexiona, Caracas 2003, pp. 139-177.

Buttó L.A., Venezuela 1992. Aproximación Histórica a las Bases Ideológicas de las Insurrecciones Militares, unpublished manuscript, Caracas 2010.

Buttó, L.A., 'Venezuela 1992: bases ideológicas de las insurrecciones militares', Asian Journal of Latin American Studies, Vol. 21, No 2 (2008), pp. 35-67.

Buttó L.A., 'Venezuela 1999-2008: Relaciones Civiles y Militares en la V República' in C. Fermín, L.A. Buttó, H. Hurtado Grooscors, Una lectura sociológica de la Venezuela actual $V$, Caracas 2009, pp. 55-104.

Cardozo Uzcátegui, A. (ed.), Chavismo. Entre la utopia y la pesadilla, Vitoria-Gasteiz (España) 2012.

Carrillo J.L., 'En las FF.AA. nos casamos con el proyecto de país del Comandante Hugo Chávez' (Interview with General Henry Rangel Silva), at <http://www.noticias24.com/actualidad/ noticia/179689/venezuela-adquirio-tanques-t72-btr-80-y-btp3-y-misiles-para-defender-las-costas>, 30 June 2011.

Chávez H.R. (speaker), Discurso pronunciado en el acto de entrega de préstamos hipotecarios a personal de la Fuerza Armada Nacional (On TV), Caracas, Venezolana de Televisión, 2 April 2007.

Chávez H.R. (speaker), Salutación de Fin de Año del presidente de la República Bolivariana de Venezuela a la Fuerza Armada Nacional (On TV), Caracas, Venezolana de Televisión, 28 December 2006.

Constitución de la República Bolivariana de Venezuela, Gaceta Oficial de la República Bolivariana de Venezuela, 5.453 (Extraordinario), 24 March 2000.

Constitución de la República de Venezuela, Gaceta Oficial de la República de Venezuela, 662 (Extraordinario), 23 January 1961.

Decreto con Rango, Valor y Fuerza de Ley Orgánica de Reforma de la Ley Orgánica de la Fuerza Armada Nacional Bolivariana, Gaceta Oficial de la República Bolivariana de Venezuela, número 8.096, 9 March 2011.

Escobar Salom R., 'El desafío autoritario', El Nacional (Caracas), 10 June 2006, p. A-7.

Espinoza M.D., 'Bajo el signo del militar-político y el ciudadano-soldado', El Universal (Caracas), 24 February 2008, p. 1-4.

Fermín C., L.A. Buttó, H. Hurtado Grooscors, Una lectura sociológica de la Venezuela actual V, Caracas 2009.

Fernández C. (presenter), Triángulo (TV Show), Caracas, TELEVEN, 25 March 2004. 
Finer S.E., Governo Comparado, Brasilia 1981.

Finer S.E., 'The morphology of military regimes' in R. Kolkowicz, A. Korbonski (eds.), Soldiers, Peasants and Bureaucrats. Civil-Military Relations in Communist and Modernizing Societies, London 1982.

Herrera Jiménez H., La Doctrina Militar Bolivariana. El Nuevo Sistema de Seguridad y Defensa Venezolano, Caracas 2006.

Irwin D., Relaciones Civiles-Militares en el Siglo XX, Caracas 2000.

Irwin D., H. Castillo, F. Langue (coords.), Pretorianismo venezolano del siglo XXI. Ensayos sobfre las relaciones civiles y militares venezolanas, Caracas 2007.

Irwin D., F. Langue (coords.), Militares y Poder en Venezuela. Ensayos históricos vinculados con las relaciones civiles y militares venezolanas, Caracas 2005.

Irwin, D., F. Langue (coords.), Militares y Sociedad en Venezuela. Un manual sobre las relaciones civiles y militares, el control civil y referencias metodológicas sobre la historia inmediata. Cuando la calle arde y el aula reflexiona, Caracas 2003.

Kolkowicz R., A. Korbonski (eds.), Soldiers, Peasants and Bureaucrats. Civil-Military Relations in Communist and Modernizing Societies, London 1982.

Loveman B., T.M. Davies Jr. (eds.), The Politics of Antipolitics. The Military in Latin America, Lincoln 1989.

Norden, D., 'Crisis without Coups in Latin America. The Role of the International Community in Sustaining Democracy', paper presented at XXV International Congress of the Latin American Studies Association, Las Vegas (USA), October 2004.

'Nuevo saludo militar: Bolivariano, Revolucionario, Antiimperialista, Socialista y Chavista', PRIMICIA.COM, Puerto Ordaz (Venezuela), 1 April 2011, at < http://www.primicia. com.ve/index.php/nacion/item/13150-nuevo-saludo-militar-bolivariano-revolucionario-antiimperialista-socialista-y-chavista.html>, 2 June 2012.

Red de Seguridad y Defensa de América Latina, 'Atlas Comparativo de la Defensa en América Latina', at <http://atlas.resdal.org.ar>, 5 May 2009.

Sala de Prensa de Minuto 59, 'Milicia Nacional Bolivariana necesita un millón y medio de voluntarios', at <http://www.minuto59.com/primera-pagina/milicia-nacional-bolivariana-necesita-un-millon-y-medio-de-voluntarios>, 2 May 2009.

Luis Alberto BUTTÓ, Professor and researcher at the Social Sciences Department and the Political Science Post grade in Simon Bolivar University, Caracas-Venezuela. Ph.D. in History. Master's degree in Development Planning. Master's degree in Communication for Defense and Armed Conflicts, Historian. Research interests: Civil-Military Relations in Contemporary Venezuela; Security and Defense in Contemporary Latin America; Epistemology of History. To date, he has published over 30 articles in compiled books and scientific journals and over 10 articles in proceedings of scientific congresses. Also, he has participated in more than 40 scientific congresses. 